BIOEDUSAINS: Jurnal Pendidikan Biologi dan Sains

Volume 1, Nomor 2, Desember 2018

e-ISSN : 2598-7453

DOI : https://doi.org/10.31539/bioedusains.v1i2.449

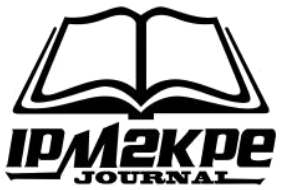

\title{
PENINGKATAN HASIL BELAJAR BIOLOGI DENGAN MODEL DISCOVERY LEARNING
}

\author{
Sri Gening Sundari \\ Sekolah Menengah Atas (SMA) Negeri 3 Lubuklinggau \\ srigeningsundari@gmail.com
}

\begin{abstract}
ABSTRAK
Tujuan penelitian ini untuk mengetahui adanya peningkatan hasil belajar biologi siswa kelas X IPA SMA Negeri 3 Lubuklinggau. Metode yang digunakan dalam penelitian ini adalah penelitian tindakan kelas (Classroom Action Research). Populasi penelitian ini adalah semua kelas X IPA. Sampel diambil dengan teknik purposive sampling sehingga diperoleh 1 kelas dengan jumlah siswa berjumlah 32 orang. Instrumen yang digunakan adalah lembar observasi dan teknik tes. Data hasil penelitian dianalisis secara deskriptif kuantitatif dan kualitatif. Data hasil penelitian menunjukkan bahwa hasil belajar siswa meningkat dari kondisi awal 37\%, siklus I 43,75 \% menjadi 59,37 \% pada siklus II. Untuk data aktivitas belajar siswa dari beberapa parameter pengamatan aktivitas belajar berupa keaktifan, responsif, kerjasama, tanggung jawab, toleran dan ketekunan dengan rata-rata jumlah nilai pada siklus I hanya 62,03 kemudian pada siklus II meningkat menjadi rata-rata nilai 79,53. Simpulan, model pembelajaran discovery learning dapat meningkatkan hasil belajar dan aktivitas belajar siswa.
\end{abstract}

Kata Kunci: hasil belajar, model discovery learning

ABSTRACT

The research aim was to find out the improvement of biology achievement of the tenth grade students of science class at SMA Negeri 3 Lubuklinggau. The research method used was Classroom Action Research. The population was all of the tenth grade students of science class. The sampling technique was purposive sampling technique with 32 students as the samples. The instruments of data collection were observation sheets and tests. The data were analyzed both through quantitative and qualitative descriptive method. The results showed that the students achievement was improved indicated by initial percentage 37\%, cycle I 43,75\% to 59,37\% in cycle II. The data of students learning activities were collected from some parameters such as students' activities, response, cooperation, responsibilities, tolerances, and diligence with the average score in cycle I only 62,03 and it was improved in cycle II to 79,53. In conclusion, discovery learning model could improve students' learning achievements and students' learning activities.

Keywords: students achievement, model discovery learning 


\section{PENDAHULUAN}

Indonesia merupakan negara berkembang yang sangat mengutamakan pendidikan. Seiring proses perkembangannya, upaya dalam perbaikan proses pembelajaran terus dilakukan. Undang-undang Nomor 20 Tahun 2003 tentang Sistem Pendidikan Nasional menjelaskan bahwa dalam pembelajaran sangat menekankan pada proses interaksi peserta didik dengan pendidik dan sumber belajar, hal ini bertujuan agar dapat mengembangkan potensi peserta didik sehingga dapat menjadi manusia yang memiliki iman dan takwa kepada Tuhan Yang Maha Esa, berakhlak mulia, sehat, berilmu, kreatif, mandiri, menjadi warga negara yang demokratis serta bertanggung jawab (Depdiknas, 2003). Selain itu, salah satu kemampuan yang sangat diharapkan dapat tercipta dalam lingkungan belajar peserta didik yaitu kemampuan berfikir tingkat tinggi (high order thinking) yang merupakan kelanjutan dari kompetensi dasar (basic skills). Kompetensi yang juga merupakan penunjang dalam belajar siswa yaitu kreativitas, karena kreativitas merupakan siklus bahwa siswa telah berfikir tingkat lanjut (Martaida, 2017).

Hasil observasi selama proses pembelajaran mata pelajaran Biologi di kelas X IPA SMAN 3 Lubuklinggau, siswa memiliki permasalahan dimana hasil belajar masih tergolong rendah. Hal dikarenakan dalam proses proses pembelajaran siswa kurang aktif dalam berdiskusi, kegiatan belajar lebih bersifat individual. dalam pembelajaran Biologi seharusnya siswa lebih aktif memecahkan suatu masalah secara bersama-sama. Karena mata pelajaran biologi berkaitan dengan cara mencari tahu dan memahami secara sistematis,sehingga biologi bukan hanya penguasaan kumpulan pengetahuan yang berupa fakta-fakta konsep dan prinsip saja tetapi juga merupakan suatu proses penemuan. Dari permasalahan tersebut, maka perlu dilakukan penelitian dengan menggunakan model yang tepat. Salah satu model pembelajaran yang dapat membuat siswa aktif (Student Centered Learning) adalah dengan penerapan model pembelajaran Discovery Learning (Nilgun, 2016).

Model discovery Learning merupakan model pembelajaran yang dalam proses pembelajarannya peserta didik harus menyampaikan ide atau gagasan melalui proses penemuan (Martaida, 2017). Menurut Akinbobola \& Afolabi (2010) penggunaan discovery learning dapat melibatkan siswa dalam kegiatan pemecahan masalah, belajar mandiri, berpikir kritis, dan pemahaman serta belajar kreatif. Discovery learning adalah model mengajar yang berusaha meletakkan dasar dan mengembangkan cara berfikir ilmiah, siswa ditempatkan sebagai subjek yang belajar, peranan guru hanya sebagai pembimbing belajar dan fasilitator belajar.

Dengan menggunakan model ini diharapkan dapat membantu guru dalam mengarahkan peserta didik untuk memahami konsep, arti, dan hubungan, melalui proses intuitif untuk akhirnya sampai kepada suatu kesimpulan. Penemuan konsep tidak disajikan dalam bentuk akhir, tetapi peserta didik didorong untuk 
mengidentifikasi apa yang ingin diketahui dan dilanjutkan dengan mencari informasi sendiri kemudian mengorganisasi atau mengkonstruksi apa yang mereka ketahui dan pahami dalam suatu bentuk akhir. peserta didik diharapkan sebagai peserta aktif dan mandiri dalam proses belajarnya, yang bertanggung jawab dan berinitiatif untuk mengenali kebutuhan belajarnya, menemukan sumber-sumber informasi untuk dapat menjawab kebutuhannya, membangun serta mempresentasikan pengetahuannya berdasarkan kebutuhan serta sumber-sumber yang ditemukannya.

\section{METODE PENELITIAN}

Penelitian dilakukan dengan metode penelitian tindakan kelas, yaitu metode penelitian yang dilakukan di dalam kelas untuk melakukan perbaikan dan pengamatan kemampuan belajar siswa. Tempat dan waktu penelitian dilaksanakan di SMAN 3 Lubuklinggau pada bulan Oktober - November 2018. Populasi penelitian ini adalah semua kelas X IPA SMA Negeri 3 Lubuklinggau Tahun ajaran 2018/2019. Sampel diambil dengan teknik purposive sampling sehingga diperoleh 1 kelas dengan jumlah siswa berjumlah 32 orang. Instrumen yang digunakan adalah lembar observasi dan teknik tes.Prosedur penelitian mengacu pada desain PTK Model Lewin yaitu terdiri dari perencanaan, pelaksanaan, observasi dan refleksi.

\section{Tahap Orientasi Masalah}

Permasalahan penelitian merupakan suatu kondisi yang tidak diharapkan keberadaannya dalam proses pembelajaran. Permasalahan tersebut merupakan temuan yang dapat dijadikan sebagai permasalahan dalam penelitian. Langkah berikutnya adalah mengidentifikasi permasalahan yang disusul dengan penyusunan kerangka pemikiran dan menyusun hipotesis awal guna mendapatkan gambaran sementara untuk melakukan pelaksanaan penelitian dalam mengatasi masalah yang telah diperoleh.

\section{Perencanaan Tindakan.}

1) Tahap Persiapan dengan mengidentifikasi permasalahan,mengumpulkan data pendukung berupa data primer dan data sekunder,menyusun daftar hadir dan alat-alat dokumentasi; 2) Implementasi Kegiatan, meliputi : inventarisir program kegiatan, menyiapkan Lembar Kegiatan Siswa, pembuatan Rencana Program Pembelajaran (RPP), menyiapkan alat dan bahan perlengkapan pembelajaran, menyiapkan alat penilaian; 3) Tahap Pemantauan dan Evaluasi, meliputi : mencatat semua kelemahan dan kekurangan, mencatat semua kendala yang timbul dalam menanggulangi kelemahan dan kekurangan; 4) Tahap Analisis dan Refleksi, meliputi; merancang kegiatan untuk menyelesaikan permasalahan yang ditemui, mengantisipasi adanya masalah yang timbul dengan penyempurnaan perencanaan dan 
pelaksanaannya, menindaklanjuti tindakan yang perlu dilakukan dalam rangka meningkatkan belajar siswa didalam proses pembelajaran Discovery Learning.

\section{Tahap Pelaksanaan Tindakan}

Setelah persiapan lapangan dan instrumen yang dibutuhkan tersedia, pelaksanaan tindakan penerapan pembelajaran berdasarkan masalah dalam pembelajaran Biologi sebagai model inovasi untuk meningkatkan prestasi siswa kelas X IPA SMAN 3 Lubuklinggau, dilakukan sebanyak 2 siklus, pada setiap siklus terdiri atas tahap-tahap berikut :

1. Perencanaan, yaitu menentukan tujuan pembelajaran, memilih materi pelajaran, mengembangkan bahan-bahan untuk dipelajari siswa, melakukan penilaian proses dan hasil belajar siswa

2. Pelaksanaan Tindakan Kelas, yaitu kegiatan proses belajar mengajar dengan model pembelajaran Discovery Learning antara peneliti dengan para siswa kelas $X$ IPA SMAN 3 Lubuklinggau, sehingga terjadi interaksi antara siswa dengan siswa, juga antara guru dengan siswa.

3. Pengamatan, yaitu pengamatan secara langsung dari peneliti terhadap aktivitas para siswa sebagai subjek bimbingan. Dengan menggunakan lembar pengamatan peneliti mengamati pelaksanaan model pembelajaran Discovery Learning sesuai dengan kompetensi dasar di tingkat yang sesuai.

4. Refleksi, yaitu kegiatan dalam usaha perbaikan untuk pertemuan kegiatan selanjutnya,dari evaluasi kekurangan pertemuan sebelumnya. Perbaikan ini bertitik tolak dari hasil pengamatan dan hasil diskusi yang dilakukan oleh peneliti dengan guru-guru observer yang membantu peneliti. Perbaikan ini dapat dilihat dalam persiapan dan perencanaan pembelajaran berikutnya.

\section{Pengumpulan Data}

Pengumpulan data dalam penelitian ini menggunakan pendekatan penelitian tindakan kelas dengan teknik :

1. Pengamatan (Observasi), observasi dilakukan oleh peneliti dan dilaksanakan pada saat proses pembelajaran berlangsung. Observasi dilakukan untuk memperoleh data aktivitas siswa dalam kelompok sekaligus mengevaluasi kekurangan-kekurangan yang ditemukan dalam kegiatan belajar mengajar, serta untuk memperoleh data kemampuan siswa dalam proses pembelajaran discovery learning.

2. Evaluasi, dilakukan terhadap hasil kerja siswa dalam proses pembelajaran secara keseluruhan untuk menilai kelengkapan, sistematik dan sistematis dari hasil belajar siswa. Aspek yang dievaluasi merupakan seluruh aspek yang dilakukan oleh siswa dalam pembelajaran discovery learning. 
3. Dokumentasi, merupakan data yang berupa visual foto yang diambil ketika kegiatan berlangsung.

\section{Analisis Data}

Data yang diperoleh dalam penelitan ini secara umum dianalisis melalui deskriptif kuantitatif kualitatif. Analisis data dilakukan pada tiap data yang dikumpulkan, baik data kuantiatif maupun data kualitatif. Data kuantiatif dianalisis dengan menggunakan cara kuantitatif sederhana, yakni persentase (\%) dan data kuantiatif dianalisis dengan membuat penilaian kuantiatif (kategori). Menurut Arikunto (2010) lima kategori predikat tersebut yaitu seperti pada tabel berikut:

Tabel 1. Klasifikasi Kategori Tingkatan dan Persentase

\begin{tabular}{c|c|c}
\hline No & Interval & Kategori \\
\hline 1 & $81-100$ & Baik Sekali \\
\hline 2 & $61-80$ & Baik \\
\hline 3 & $41-60$ & Cukup \\
\hline 4 & $21-40$ & Kurang \\
\hline 5 & $0-20$ & Sangat Kurang \\
\hline
\end{tabular}

Untuk menilai ulangan atau tes formatif.Peneliti melakukan penjumlahan nilai yang diperoleh peserta didik, yang selanjutnya dibagi dengan jumlah peserta didik yang ada di kelas tersebut sehingga diperoleh rata-rata tes formatif. Selanjutnya penilaian dengan lembar observasi aktivitas siswa. Analisis data lembar observasi aktivitas siswa dilakukan saat kegiatan belajar mengajar berlangsung.

\section{HASIL PENELITIAN}

Hasil dari proses pembelajaran pada kondisi awal yaitu siswa masih belum terbiasa dengan menggunakan model Discovery Learning, masih banyak siswa kurang berperan aktif dalm proses diskusi yang dilaksanakan. Rasa malu-malu dan merasa tidak percaya diri dengan jawaban yang akan diberikan, membuat mereka tidak berani mengemukan pendapat. Hal ini menyebabkan rata-rata hasil belajar Biologi pada materi keanekaragaman hayati menjadi rendah. Berikut hasil belajar yang diperoleh tertera pada Tabel 2 . berikut:

Tabel 2. Data Hasil Belajar Kondisi Awal

\begin{tabular}{llccc}
\hline No & Kriteria & Rentang Nilai & Jumlah & Persentase \\
\hline 1 & Belum Mencapai KKM & $0-74$ & 20 & $62,5 \%$ \\
\hline 2 & Sudah Mencapai KKM & $75-100$ & 12 & $37,5 \%$ \\
\hline
\end{tabular}


Dari Tabel tersebut diketahui bahwa data hasil belajar pada kondisi awal siswa memiliki persentasenya yaitu sebesar $62,5 \%$ sedangkan yang mencapai KKM yaitu sebesar $37,5 \%$.

\section{Deskripsi Data Hasil Penelitian Siklus I}

Pada Siklus I ini, Guru menyusun berbagai kegiatan berupa:

1. Perencanaan Tindakan. Kegiatan yang telah dilakukan pada tahap perencanaan tindakan di siklus 1 yaitu berupa penyusunan Rencana Pelaksanaan Pembelajaran (RPP), menetapkan model yang tepat untuk mengatasi permasalahan yang ada di kelas, selanjutnya guru memutuskan bahwa model yang tepat yaitu Discovery Learning, merumuskan lembar aktivitas siswa, lembar bahan yang akan didiskusikan siswa, serta perencanaan untuk mengadakan evaluasi belajar pada siklus 1 .

2. Pelaksanaan Tindakan. Dari data siklus 1 yang dilaksanakan pada bulan November 2018, kegiatan proses belajar berjalan dengan lancar. Berikut data hasil pelaksanaan tindakan pada pertemuan 1. Persentase data hasil belajar pada siklus 1 yaitu sebesar 56,25\% belum mencapai KKM, dan hasil belajar yang belum mencapai KKM yaitu sebesar $43,75 \%$.

Tabel 3.Data Hasil Belajar Siklus I

\begin{tabular}{lllll}
\hline No & Kriteria & $\begin{array}{l}\text { Rentang } \\
\text { Nilai }\end{array}$ & Jumlah & Persentase \\
\hline 1 & Belum Mencapai KKM & $0-74$ & 18 & $56,25 \%$ \\
\hline 2 & Sudah Mencapai KKM & $75-100$ & 14 & $43,75 \%$ \\
\hline
\end{tabular}

3. Pengamatan/ Observasi. Pada saat pembelajaran berlangsung dilakukan pengamatan terhadap aktifitas belajar siswa dengan menggunakan lembar observasi. Data aktivitas siswa yang diamati yaitu keaktifan, responsif, kerjasama, tanggung jawab, toleransi, dan ketekunan selama proses pembelajaran Biologi dengan menggunakan model discovery learning. Berikut Tabel 4. rekapitulasi data aktivitas belajar siswa pada siklus 1 .

Tabel 4. Rekapitulasi Aktivitas Siswa Pada Siklus I

\begin{tabular}{clccccccc}
\hline No & $\begin{array}{l}\text { Kode } \\
\text { Siswa }\end{array}$ & Aktif & Responsif & Kerjasama & $\begin{array}{c}\text { Tanggung } \\
\text { jawab }\end{array}$ & Toleran & Tekun & Nilai \\
\hline 1 & AK & 1 & 2 & 1 & 2 & 3 & 2 & 46 \\
\hline 2 & AN & 2 & 2 & 2 & 2 & 1 & 2 & 46 \\
\hline 3 & AW & 3 & 2 & 2 & 2 & 1 & 2 & 50 \\
\hline 4 & BS & 3 & 2 & 3 & 2 & 1 & 3 & 58 \\
\hline
\end{tabular}




\begin{tabular}{|c|c|c|c|c|c|c|c|c|}
\hline 5 & BK & 3 & 3 & 3 & 3 & 3 & 2 & 71 \\
\hline 6 & $\mathrm{BU}$ & 3 & 2 & 3 & 3 & 3 & 3 & 71 \\
\hline 7 & $\mathrm{CC}$ & 3 & 3 & 3 & 3 & 2 & 3 & 71 \\
\hline 8 & CL & 2 & 2 & 3 & 2 & 3 & 2 & 58 \\
\hline 9 & DK & 3 & 3 & 3 & 2 & 3 & 3 & 71 \\
\hline 10 & GP & 3 & 3 & 3 & 2 & 3 & 3 & 71 \\
\hline 11 & GA & 3 & 3 & 2 & 3 & 3 & 2 & 67 \\
\hline 12 & $\mathrm{HS}$ & 3 & 1 & 3 & 2 & 2 & 2 & 54 \\
\hline 13 & LA & 3 & 3 & 3 & 3 & 3 & 3 & 75 \\
\hline & MG & 2 & 3 & 3 & 3 & 2 & 3 & 67 \\
\hline & MY & 2 & 3 & 3 & 3 & 2 & 3 & 67 \\
\hline & $\mathrm{MF}$ & 3 & 3 & 3 & 3 & 3 & 3 & 75 \\
\hline 17 & $\mathrm{NO}$ & 3 & 3 & 3 & 2 & 2 & 2 & 63 \\
\hline & NS & 3 & 1 & 3 & 2 & 3 & 2 & 58 \\
\hline & RM & 2 & 1 & 3 & 3 & 2 & 3 & 58 \\
\hline 20 & RK & 2 & 3 & 3 & 3 & 3 & 2 & 67 \\
\hline 21 & SU & 2 & 1 & 3 & 3 & 3 & 2 & 58 \\
\hline 22 & SA & 3 & 3 & 3 & 3 & 3 & 2 & 71 \\
\hline 23 & SN & 2 & 3 & 3 & 3 & 1 & 2 & 58 \\
\hline 24 & SJ & 2 & 2 & 3 & 2 & 1 & 2 & 50 \\
\hline 25 & SL & 3 & 3 & 3 & 3 & 2 & 2 & 67 \\
\hline 26 & SP & 2 & 2 & 3 & 2 & 3 & 2 & 58 \\
\hline 27 & TA & 3 & 3 & 3 & 2 & 2 & 2 & 63 \\
\hline 28 & WH & 3 & 3 & 2 & 2 & 2 & 2 & 58 \\
\hline 29 & YK & 2 & 2 & 2 & 2 & 2 & 2 & 50 \\
\hline 30 & YP & 3 & 3 & 2 & 3 & 3 & 2 & 67 \\
\hline 31 & YP & 3 & 3 & 2 & 3 & 2 & 2 & 63 \\
\hline 32 & $\mathrm{ZK}$ & 3 & 2 & 2 & 2 & 3 & 2 & 58 \\
\hline \multicolumn{8}{|c|}{ Rata-rata } & 62,03 \\
\hline
\end{tabular}

Dari Tabel 4 data tentang aktivitas belajar siswa diketahui bahwa rata-rata aktivitas siswa dengan nilai 62,03.

4. Refleksi. Kegiatan refleksi pada siklus 1 ditemukan beberapan permasalahan yaitu hasil tes belajar siswa masih banyak yang dibawah KKM, kemudian data ativitas belajar siswa juga berjumlah 62,03. Hal ini dikarenakan siswa masih belum terbiasa dengan menalihkan pembelajaran yang selama ini lebih bersifat 
mandiri kemudian menjadi kooperatif. Siswa mampu memecahkan permasalahan yang diberikan guru. Akan tetapi kegiatan diskusi tersebut masih belm optimal. Ada beberapa siswa di dalam kelompoknya yang masih mengandalkan temannya yang lebih pandai, dan lebih banyak diam. Sehingga hal ini berpengaruh pada nilai aktivitas belajar siswa tersebut.

Kegiatan pada siklus II melanjutkan dari apa yang telah dilakukan pada siklus 1. Kegiatan ini adalah perbaikan proses pembelajaran mata pelajaran Biologi agar menjadi lebih baik.

1. Perencanaan Tindakan. Kegiatan yang dilakukan oleh guru yaitu menyusun beberapa instrumen yang lebih menarik, disertai gambar-gambar yang sesuai dengan permasalahan di kehidupan sehari-hari. Sehingga siswa lebih mudah untuk memahami dan mengkaitkan materi yang diberikan dengan permasalahan kehidupan sehari-hari. Selanjutnya peneliti melakukan penyusunan RPP, dan sistem evaluasi berupa tes dan non tes untuk siswa pada siklus II.

2. Pelaksanaan Tindakan. Kegiatan pelaksanaan pembelajaran pada siklus II berjalan dengan lancar dan pembelajaran menjadi sangat aktif. Hasil belajar yang diperoleh siswa menjadi lebih baik pada siklus II ini. Sebanyak 59,37\% siswa telah mencapai KKM (sebanyak 19 orang) sedangkan 5 orang lagi masih dibawah standar akan tetapi nilai yang diperoleh adalah mendekati KKM yang ditetapkan (75). Berikut hasi belajar setelah diberikan tindakan pada siklus II secara lengkap dapat penulis paparkan pada tabel di bawah ini.

Tabel 5. Data Hasil Belajar Siklus II

\begin{tabular}{lllll}
\hline No & Kriteria & Rentang Nilai & Jumlah & Persentase \\
\hline 1 & $\begin{array}{l}\text { Belum Mencapai } \\
\text { KKM }\end{array}$ & $0-74$ & 5 & $15,62 \%$ \\
\hline 2 & $\begin{array}{l}\text { Sudah Mencapai } \\
\text { KKM }\end{array}$ & $75-100$ & 19 & $59,37 \%$ \\
\hline
\end{tabular}

3. Pengamatan/ Observasi. Hasil observasi dan pengamatan terlihat bahwa semua siswa aktif bertanya dengan temannya, semua orang di dalam tim kelompoknya bertanggung jawab ketika menjawab pertanyaan yang diberikan oleh guru maupun oleh temannya dari kelompok lain. Berikut Tabel 6. Data rekapitulasi hasil observasi aktivitas siswa pada siklus II.

Tabel 6. Rekapitulasi Hasil Observasi Aktivitas Siswa Siklus II

\begin{tabular}{llccccccc}
\hline No & $\begin{array}{l}\text { Kode } \\
\text { Siswa }\end{array}$ & Aktif & Responsif & $\begin{array}{c}\text { Kerjasa } \\
\text { ma }\end{array}$ & $\begin{array}{c}\text { Tanggung } \\
\text { jawab }\end{array}$ & Toleran & $\begin{array}{c}\text { Tekun } \\
\text { Jumlah } \\
\text { Skor }\end{array}$ \\
\hline 1 & AK & 3 & 3 & 4 & 3 & 3 & 2 & 75 \\
\hline 2 & AN & 3 & 3 & 4 & 4 & 3 & 4 & 86 \\
\hline 3 & AW & 3 & 3 & 4 & 3 & 3 & 2 & 75 \\
\hline
\end{tabular}




\begin{tabular}{|c|c|c|c|c|c|c|c|c|}
\hline 4 & BS & 3 & 3 & 3 & 2 & 4 & 3 & 75 \\
\hline 5 & BK & 3 & 3 & 4 & 3 & 3 & 2 & 75 \\
\hline 6 & BU & 3 & 4 & 4 & 3 & 3 & 3 & 83 \\
\hline 7 & $\mathrm{CC}$ & 3 & 3 & 4 & 3 & 3 & 3 & 79 \\
\hline 8 & $\mathrm{CL}$ & 4 & 4 & 4 & 4 & 3 & 4 & 92 \\
\hline 9 & DK & 3 & 3 & 3 & 2 & 4 & 3 & 75 \\
\hline 10 & GP & 3 & 3 & 3 & 2 & 4 & 3 & 79 \\
\hline 11 & GA & 3 & 3 & 2 & 3 & 4 & 3 & 75 \\
\hline 12 & HS & 4 & 4 & 4 & 4 & 3 & 4 & 96 \\
\hline 13 & LA & 3 & 3 & 3 & 3 & 3 & 3 & 75 \\
\hline 14 & MG & 3 & 3 & 3 & 3 & 3 & 3 & 75 \\
\hline 15 & MY & 3 & 3 & 3 & 3 & 3 & 3 & 75 \\
\hline 16 & MF & 3 & 3 & 3 & 3 & 3 & 3 & 75 \\
\hline 17 & $\mathrm{NO}$ & 3 & 3 & 4 & 4 & 3 & 4 & 86 \\
\hline 18 & NS & 3 & 3 & 3 & 4 & 3 & 2 & 75 \\
\hline 19 & $\mathrm{RM}$ & 3 & 3 & 3 & 3 & 3 & 3 & 75 \\
\hline 20 & RK & 4 & 3 & 4 & 3 & 3 & 2 & 75 \\
\hline 21 & $\mathrm{SU}$ & 4 & 3 & 3 & 3 & 3 & 4 & 83 \\
\hline 22 & SA & 3 & 3 & 4 & 3 & 3 & 2 & 75 \\
\hline 23 & SN & 4 & 3 & 4 & 3 & 3 & 4 & 86 \\
\hline 24 & SJ & 4 & 4 & 4 & 4 & 3 & 4 & 96 \\
\hline 25 & $\mathrm{SL}$ & 3 & 3 & 3 & 3 & 4 & 2 & 75 \\
\hline 26 & SP & 3 & 3 & 3 & 3 & 3 & 2 & 75 \\
\hline 27 & TA & 3 & 3 & 3 & 4 & 3 & 2 & 75 \\
\hline 28 & WH & 3 & 3 & 3 & 3 & 4 & 2 & 75 \\
\hline 29 & YK & 4 & 4 & 4 & 4 & 3 & 4 & 96 \\
\hline 30 & YP & 3 & 3 & 4 & 3 & 3 & 2 & 75 \\
\hline 31 & YP & 3 & 3 & 3 & 3 & 4 & 2 & 75 \\
\hline 32 & ZK & 3 & 4 & 4 & 4 & 3 & 2 & 83 \\
\hline
\end{tabular}

Keterangan: 1 (Kurang), 2 (Cukup), 3 (Baik), 4 (Sangat Baik)

Dari Tabel tersebut terlihat rata-rata data aktivitas belajar siswa pada siklus II yaitu 79,53. Artinya telah mencapai KKM. Grafik hasil belajar tersebut dapat dilihat pada Gambar 1 berikut, materi keanekaragaman hayati pra siklus, siklus I, dan siklus II, ditunjukkan pada gambar berikut :

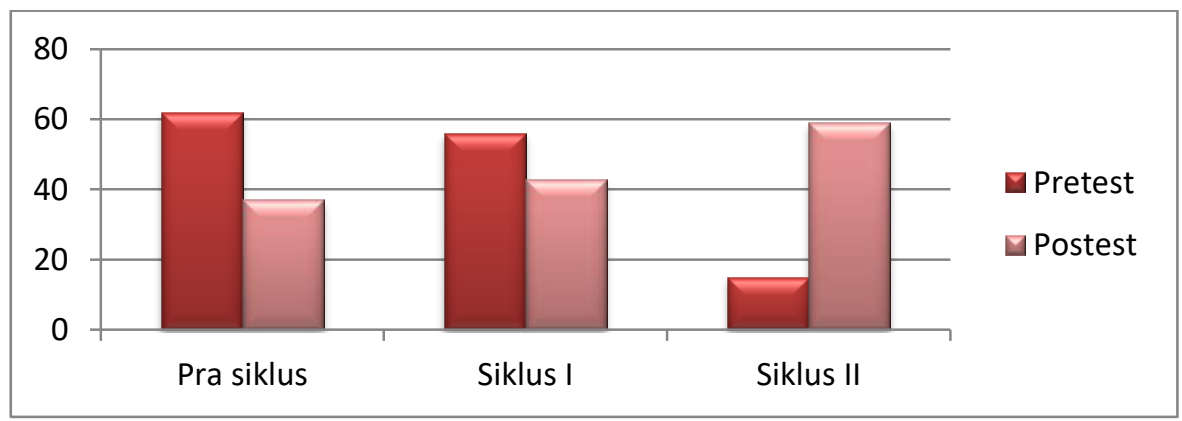

Gambar 1. Grafik Data Hasil Belajar Siswa 
Dari grafik hasil belajar pada materi keanekaragaman hayati tersebut, dapat diketahui perbandingan adanya peningkatan data postest setelah penerapan pada siklus II. Hal ini karena peneliti melakukan perbaikan terhadap refleksi pada siklus I sehingga kekurangan yang ada pada pertemuan sebelumnya menjadi perbaikan pada siklus II. Dari aktivitas siswa juga diketahui bahwa siswa sangat semangat belajar dan menemukan jawaban dari permasalahan yang diberikan guru. Berikut Gambar 2. Data aktivitas belajar siswa mengalami peningkatan dari siklus 1 yang masih dibawah 75 yaitu sebesar 62,03 sedangkan aktivitas siswa pada siklus II menjadi 79,53.

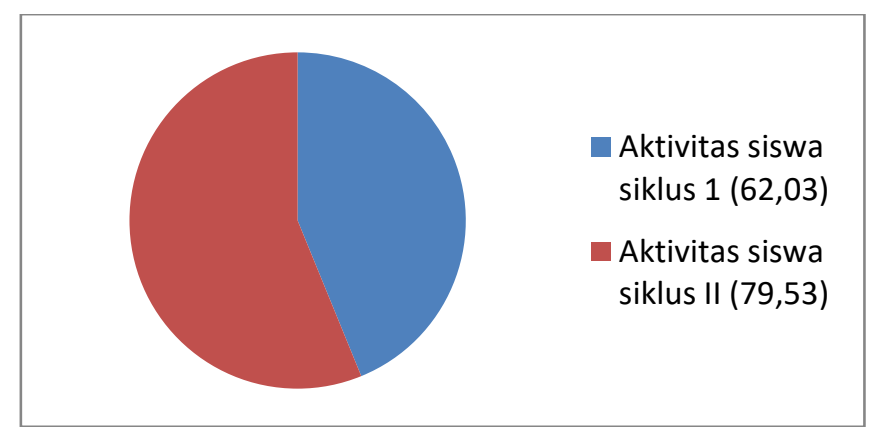

\section{Gambar 2. Aktivitas belajar siswa}

4. Refleksi. Hasil belajar siswa kelas X SMAN 3 Lubuklinggau pada materi keanekaragaman hayati pada siklus II semua siswa aktif berdiskusi dan proses pembelajaran mencapai apa yang diharapkan, karena sebagian besar telah mencapai KKM yang telah ditetapkan sebesar 59,37\%.

\section{PEMBAHASAN}

Berdasarkan penelitian yang telah dilakukan pada pra siklus, siklus 1 dan siklus II pada materi keanekaragaman hayati mata pelajaran Biologi kelas X SMA Negeri 3 Lubuklinggau tahun ajaran 2018/2019 terdapat peningkatan hasil belajar pada siklus II. Tahap pada siklus 1 yaitu sebanyak 14 orang yang belum mencapai KKM. Pada tahap siklus II meningkat menjadi 19 orang $(59,37 \%)$. Data hasil aktivitas belajar siswa juga meningkat. Pada siklus I nilai rata-rata yang diperoleh yaitu 62 sedangkan pada siklus II data aktivitas siswa menjadi 79. Siswa yang belum terbiasa menggunakan metoda belajar yang berbeda membuat nilai hasil belajar dan aktivitas belajar masih di bawah KKM pada siklus I. Sedangkan pada siklus II siswa telah terbiasa dengan metoda pembelajaran yang diterapkan oleh guru. Pada siklus II hanya 5 orang siswa yang memiliki hasil belajar dibawah KKM. Hal ini dikarenakan siswa tersebut merupakan siswa yang memiliki semangat belajar yang rendah. Hal ini diketahui dari beberapa hasil analisis melalui hasil analisis ulangan siswa pada setiap 
pokok bahasan. Penelitian yang telah dilakukan oleh Balim (2009) mengungkapkan bawa data yang diperoleh dari hasil penelitiannya memiliki perbedaan antara kelas kontrol dan kelas eksperimen yang diberikan model discovery learning. Terdapat signifikansi dari rata-rata hasil belajar, persepsi keterampilan belajar, baik pada tingkat kognitif dan afektif pada kelas yang diberikan model discovery learning, siswa juga aktif dalam menemukan solusi dari permasalahan yang diberikan guru melalui aktif menggunakan laboratorium sains di sekolah.

Ajewole (1991), memaparkan bahwa analisis hasil belajar biologi menggunakan metode penemuan dapat memungkinkan pembelajar untuk menunjukkan sikap yang lebih baik terhadap pengenalan masalah dan penyelesaian masalah daripada ketika pembelajaran dilakukan dengan metode ekspositori. Menurut Gijlers (2005), dalam pembelajaran dengan model discovery learning juga siswa dituntut untuk dapat melakukan penyelidikan sehingga pengetahuan yang diperoleh siswa sebelumnya mempengaruhi pengembangan pengetahuan selama pembelajaran penemuan kolaboratif (diskusi). Selanjutnya, pembelajaran Discovery Learning mengembangkan cara belajar aktif dimana siswa menemukan sendiri, menyelidiki sendiri maka hasil yang akan diperoleh akan tahan lama dalam ingatan, serta tidak mudah dilupakan oleh siswa (Astuti, 2018). Selanjutnya prinsip dari model pembelajaran discovery learning membuat siswa ingatan yang kuat terhadap materi yang diberikan, hal ini didukung oleh pendapat, Suprihatiningrum (2013) mengatakan bahwa dalam pembelajaran penemuan, siswa didorong untuk belajar aktif melalui keterlibatan aktif mereka sendiri dengan konsep-konsep, prinsip-prinsip. Guru memotivasi siswa siswa untuk memiliki pengalaman dan melakukan percobaan yang memungkinkan mereka menemukan prinsip-prinsip untuk diri mereka sendiri. Salah satu keunggulan model ini materi yang dipelajari lebih lama membekas karena siswa dilibatkan langsung dalam proses menemukannya.

\section{SIMPULAN}

Dari penelitian yang telah dilakukan mengenai pengaruh model pembelajaran dengan model Discovery Learning pada mata pelajaran Biologi kelas X SMA Negeri 3 Lubuklinggau dapat ditarik kesimpulan bahwa model pembelajaran Discovery learning dapat meningkatkan hasil belajar siswa dan aktivitas belajar siswa. Hasil belajar siswa meningkat dari kondisi awal 37\%, siklus I 43,75 \% menjadi 59,37\% pada siklus II. Untuk data aktivitas belajar siswa dari beberapa parameter pengamatan aktivitas belajar berupa keaktifan, responsif, kerjasama, tanggung jawab, toleran dan ketekunan dengan rata-rata jumlah nilai hanya 62,03 kemudian pada siklus meningkat menjadi rata-rata untuk 32 orang siswa memiliki nilai 79,53. 


\section{DAFTAR PUSTAKA}

Ajewole, G.A. (1991). Effects of discovery and expository instructional methods on the attitude of students to biology. Journal of Research in Science teaching: $28(5)$

Akinbobola, A. O., \& Afolabi, F. (2010). Analysis of Science process skills in West African senior secondary school certificate Physics practical examinations in Nigeria. American-Eurasian Journal of Scientific Research, 5 (2); 234-240.

Arikunto, S. (2010). Prosedur Penelitian Suatu Pendekatan Praktik. Jakarta: Rineka Cipta.

Astuti , T.E. Idrus,I \& Yennita. (2018). Penerapan Model Pembelajaran Discovery Learning Untuk Meningkatkan Hasil Belajar Pada Materi Biologi Siswa SMP. Diklabio: Jurnal Pendidikan dan Pembelajaran Biologi, 2(1); 5-9

Balım, A., G. (2009). The Effects of Discovery Learning on Students' Success and Inquiry Learning Skills. Egitim Arastirmalari Eurasian Journal of Educational Research, 35 (3); 1-20.

Depdiknas. Undang-undang RI No. 20 tahun 2003 tentang sistem pendidikan nasional.

Gijlers, H., \& de Jong, T. (2005).The relation between prior knowledge and students' collaborative discovery learning processes. Journal of Research in Science Teaching, 42 (1); 264-282.

Martaida, T., Bukit, N \& Ginting, E.M. (2017). The Effect of Discovery Learning Model on Student's Critical Thinking and Cognitive Ability in Junior High School. IOSR Journal of Research \& Method in Education (IOSR-JRME). 7 (6)

Nilgun \& Atan, H. (2016). Effects Of Discovery Learning And Student Assessment On Academic Success.The Turkish Online Journal of Educational Technology: TOJET

Suprihatiningrum, J. (2013). Strategi Pembelajaran (teori dan aplikasi). Jogjakarta: Arruz Media. 